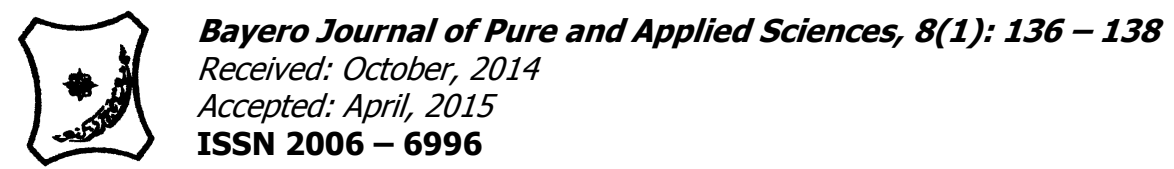

\title{
DRY SEASON PREVALENCE OF CONTAGIOUS BOVINE PLEUROPNEUMONIA BASED ON POSTMORTEM EXAMINATION AT HADEJIA ABATTOIR, JIGAWA STATE
}

\author{
Gumel, M.A., ${ }^{1}$ Qadeer, M.A., ${ }^{2}$ Ghali, M.H. ${ }^{1}$ and Kazaure, L.A. ${ }^{1}$ \\ 1. Department of Animal Health and Production, Binyaminu Usman College of Agriculture, Hadejia, Jigawa \\ State. \\ 2. Department of Biological Sciences, Modibbo Adama University of Technology, Yola, Adamawa State. \\ * Correspondenceauthor: Mag370245@gmail.com Tel: 08035950120
}

\begin{abstract}
The current prevalence study of CBPP was conducted at Hadejia abattoir of Jigawa state, Nigeria using postmortem examination of CBPP lesions in lungs of cattle at slaughter. A total of 172 slaughtered cattle were examined at postmortem over the period of 3 months (March - May, 2014). Of the total, 5(2.9\%) were positive for the presence of CBPP lesions. The disease was significantly higher $(P<0.05)$ in females $4(8.3 \%)$ than in males $1(1.8 \%)$. Cattle within the rage of 3.5 - 4 years $3(9.7 \%)$ were significantly $(P<0.05)$ infected than other age groups. Breed specific prevalence was highest 1(6.7\%) in Sokoto gudali and lowest 1(3.1\%) in white Fulani. This study concluded that CBPP is endemic and its prevalence is on the increase in the study area.

Key words: Contagious bovine pleuropneumonia, postmortem, prevalence, vaccination, abattoir, slaughtered.
\end{abstract}

\section{INTRODUCTION}

Nigeria is blessed with abundant livestock resources with most of the animals concentrated in the northern parts of the country (Egwu et al., 1995). In West Africa, ruminants play a critical role in providing protein (meant and milk) and non - food commodities (hides, skin and manure). They equally serve as a cash reserve and a form of savings for rural people and as protection against crop failure (Penin and Mahibile, 1997; Itty et al., (1997). Hence the number of the animals is very critical. However, a major constraints to this is the manase of infectious disease often associated with high morbidity, mortality and a decline in productive and reproductive performance and furthermore public health concern (Odo, 2003). Principal among these diseases is contagious bovine pleuropneumonia (CBPP) of cattle and water buffaloes (Masiga et al., 1995). The disease is infectious and highly contagious and is caused by microorganism Mycoplasma mycoides. Var. mycoides (Aliyu et al., 2000).

Transmission of the disease occurs from direct and repeated contact between sick and healthy animals (Nawathe, 1992). The disease is endemic in Nigeria Bamaiyi and Wade, (2011) and has a worldwide distribution (Blood et al., 1992). It is a major threat to cattle health and production and also the most significant epidemic disease in Africa and Nigeria (OIE, 1995). All animal ages are effected and major organ involved is the lungs (Joves et al., 2009).

Affected animals exhibits pyrexia, anorexia, dyspnoe, loss of condition, coughing and eventually die (Aliyu et al., 2000). The disease continues to rise in Nigeria and especially in Jigawa state due to nomadism (Adekunle et al., 2002). It is critical limiting factor to livestock development in Africa and especially Nigeria where it is responsible for decrease in cattle (Nawathe, 1992). The economic loss due to the disease in Nigeria was estimated to be over 1.5 million US dollars (Egwu et al., 1996). There is paucity of current status of the disease in terms of its distribution, prevalence and prophylaxis in Jigawa state. This study was conducted to identify some aspects of disease dynamics through investigation of prevalence encountered at slaughter in Hadejia abattoir as a possible indication of what obtains in Jigawa state and eventually could serve as an aid in planning preventive and control programmes.

\section{MATERIALS AND METHODS \\ Study Area}

This study was conducted at Hadejia abattoir, Jigawa state of northern Nigeria. It is the major or central abattoir in Hadejia Emirate which is owned and managed by the Jigawa State Government. The state lies between latitude $11^{\circ} 14^{\prime \prime}$ and $13^{\circ} 09^{\prime \prime} \mathrm{N}$ and longitude $8^{\circ} 00 \mathrm{E}$ to $10^{\circ} 15^{\prime \prime} \mathrm{E}$ (Mikail, 2001). It occupies a total land area of $2415 \mathrm{~km}^{2}$ and has a unique climate with relative rapid changes in temperature and humidity. Up to $60 \%$ of the area is considered characteristically dry. Most of the state fall within the Sahel savannah vegetation belt (Mikail, 2001). Some traces of Sudan savannah vegetation is found in parts of the southern district. These areas are characterized by open grassland with few scattered tall and stunted trees.

\section{Study Population}

Hadejia abattoir has an average slaughter of 14 cattle per day. A weekly visit was made to the abattoir for period between March to May, 2014. During which all cattle at slaughter were examined. A total of 172 cattle were used during sampling and for each animals sex, age and was recorded. Age was determined from rostral dentition and number of cornual rings on their horns (Gyang, 1987). Group A 2.5 - 3; Group B 3.5 - 4 and Group C 4.5 - above years. 


\section{Procedures for Postmortem Inspection of the Thoracic Cavity and Its Contents}

Meat inspection at Hadejia abattoir was carried out by the officials of Veterinary division of Jigawa State Ministry of Agriculture. All operation in the abattoir were manual and records are kept by the management. Postmortem inspection was carried out according to the method describe by Thornton's and Gracey (1981). At postmortem CBPP pathognomonic lesions in lungs and thoracic cavity (large amount of pleural effusion and heavy deposits of fibrin into thoracic cavity, lungs substance consolidation, gray and red hepatization of lobules and distensions of interlobular septum with serofibrinous exudates giving marbled lungs) were examined.

\section{Statistical Analysis}

Data obtained was analyzed to generate descriptive statistics such as means, percentage, and tables. Chi - square was used to establish association between CBPP infections and sex, age and breed. Student ttest and Anova were used to determine the significance of difference in means distribution of the CBPP between the variables (Statistical Analysis System Institute, 1989).

\section{RESULTS}

A total of 172 cattle were slaughtered and examined at Hadejia abattoir, Jigawa state for the period under study (March - May, 2014). Of the total, 57(33.1\%) were males while $115(66.9 \%)$ were females. Five cattle were identified with gross lesions of varying degrees in their lungs suggestive of CBPP giving a dry season prevalence of $2.9 \%$ (Table 1 ). Dry season distribution of CBPP by sex is significantly higher in females $4(8.3 \%)$ than in males $1(1.8 \%)(P<0.05)$ as showed in table 1 . Age related dry season distribution of CBPP revealed that, those of age range 3.5 - 4 years had the highest prevalence rate of $3(9.7 \%)$ and the lowest was those within age range of 4.5 - above years $1(0.8 \%)$ as indicated in table 2 . There was variation with respect to age and chi square analysis showed no significant difference $(P<0.05)$ in prevalence rate among age group. The dry season distribution of CBPP amongst breeds of cattle slaughtered and examined as given in table 3 indicated that Sokoto gudali had the highest $10(6.7 \%)$ and the lowest was Red bororo 3(3.4\%). Chi-square statistical analysis indicated that there was significant difference $(P<0.05)$ in dry season prevalence between breeds of cattle.

Table 1: Dry season distribution of CBPP in Cattle slaughtered at Hadejia abattoir Jigawa state.

\begin{tabular}{lccc}
\hline Sex & No. examined & No. Infected & \% Infected \\
\hline Male & 57 & 1 & 1.8 \\
Female & 115 & 4 & 8.3 \\
Total & 172 & 5 & 2.9 \\
\hline
\end{tabular}

Table 2: Dry season distribution of CBPP in Cattle slaughtered at Hadejia abattoir by age in Jigawa state.

\begin{tabular}{lccc}
\multicolumn{1}{c}{ state. } & No. examined & No. Infected & \% Infected \\
\hline Age/years & 16 & 1 & 6.3 \\
\hline $2.5-3$ & 31 & 3 & 9.7 \\
$3.5-4$ & 125 & 1 & 0.8 \\
$4.5-$ above & 172 & 5 & 2.9 \\
\hline
\end{tabular}

Table 3: Dry season distribution of CBPP in Cattle slaughtered by breeds at Hadejia abattoir Jigawa state.

\begin{tabular}{lccc}
\hline Breed & No. examined & No. Infected & \% Infected \\
\hline Red bororo & 125 & 3 & 3.4 \\
White Fulani & 32 & 1 & 3.1 \\
Sokoto gudali & 15 & 1 & 6.7 \\
Total & 172 & 5 & 2.9 \\
\hline
\end{tabular}

\section{DISCUSSION}

Detection of CBPP lesions in the lungs of cattle at postmortem is easy, cheap and adequate process for initial survey of the disease at slaughter in abattoirs. Other methods far more sensitive, but demand special equipments, skills, power supply, cumbersome, time consuming and expensive (Nawathe, 1992). This study revealed dry season CBPP prevalence of $2.9 \%$ in Hadejia abattoir which is higher than the $0.13 \%$ reported by Adamu and Aliyu (2006) in Maiduguri abattoir in a similar investigation. Furthermore, the results of this study showed that CBPP is still endemic in the study area and can be associated to inadequate vaccination coverage, breakdown of veterinary services, increased and unrestricted cattle movements, lack of vaccine efficacy, inadequate government funding and trained personnel Adekunle et al., (2002). Also, this study showed that females were more significantly $(P<0.05)$ affected than males. This can be attributed to the fact that females are more exposed to stress of pregnancy and milking which reduces their body defense against infectious diseases. Age distribution of CBPP at slaughter revealed that those within age range of $3.5-4$ years $3(9.7 \%)$ were significantly infected than other age groups. All ages of cattle are susceptible but young cattle develop joints swellings rather than lungs infections and gross pathology is obviously vivid in chronically infected cattle which are older Bamaiyi and Wade (2011). 


\section{Bajopas Volume 8 Number 1June, 2015}

Breed distribution of CBPP at Hadejia abattoir showed that Sokoto gudali had higher prevalence rate than other breeds studies. This may not be unconnected with how prone this indigenous breed is to the devastating effects of feeds scarcity in dry season. Furthermore, CBPP is common place in cattle herds that are subjected to prolonged period of feed shortages with inter-current diseases (Trypanosomes) and long distance grazing which convert lungers into active infection Joses et al., (2009).

\section{REFERENCES}

Adamu, J.Y. and Aliyu, M.M. (2006). Prevalence of Contagious Bovine Pleuropneumonia in Borno State, Nigeria. Nigerian Veterinary Journal 27(2): $14-22$.

Adekunle, O.A., Oladele, O.I. and Olukaiyeja, T.D. (2004). Indigenous Control Methods for Pests and Disease of Cattle in Northern Nigeria. Livestock Research for Rural Development 14(2): $121-130$.

Aliyu, M.M., Obi, T.U. and Egwu, G.O. (2000). Prevalence of Contiguous Bovine Pleuropneumonia (CBPP) in Northern Nigeria. Preventive Veterinary Medicine, 47(4). 263 - 269.

Aliyu, N.M., Obi, T.U. and Egwu, G.O. (2000). Prevalence of Contagious Bovine Pleuropneumonia (CBPP) in Northern Nigerian. Preventive Veterinary Medicine. 47(4): $263-269$.

Bamaiyi, P.H. and Wade, A. (2011). Molecular Epidemiology of Contagious Bovine Pleuropneumonia in Nigeria $R e$. ContinentalJournal Veterinary Sciences 5(2): $1-5,2011$.

Blood, D.C., Radostits, O.M. and Gray, C.C. (1995). Veterinary Medicine. A Textbook of Diseases of Cattle, Pigs, Goats, and Horse. $8^{\text {th }}$ ed. ELBS London Bailieve Tindal. 910 - 913.

Done, S.H., Nicholas, R.A.J., Ameh, J.A. and Palmer, N. (1996). Contagious Bovine Pleuropneumonia: An Update. Veterinary Bulleting. 66 (9): $875-888$.

Egwu, G.O., Nicholas, R.A.J., Ameh, J.A. and Bashirridin, J.B. (1996). Contagious bovine pleuropneumonia: An Update Veterinary Bulletin. 66(4): $875-888$.

Egwu, G.O., Onyeyili, P.A., Chubbtzo, G.A. and Ameh, J.A. (1995). Improved Productivity of Goats and Utilization of Goat Milk in Nigeria. Small Ruminant Research, 16: 195 - 201.

Gyang, E.O. (1987). Introduction to large animal surgery. $1^{\text {st }}$ ed. A.B.U. Press, Pp. 192195.

Itty, P., Anke3rs, P, Zinnstag, J., Trawwlly, S. and Pfister, K. (1997). Productivity and Profitability of Sheep Production in Gambia: Implication for Livestock Development in West Africa. 0 . Journal International Agriculture 36: 1653 - 172.

\section{CONCLUSION AND RECOMMENDATIONS}

It can be concluded from the result of this study that, CBPP is endemic in the study area and its prevalence is on the increased. Therefore, in view of its devastating economic implications and with the escalating trend of the highly contagious is, it is critical that more concern be given to the surveillance, prevention, control and eradication of the disease through provision of potent vaccines, vaccination, diagnostic services in enzootic areas and the payment of compensation for compulsory slaughter. It will not be out of place to recommend for more research into the epidemiology and dynamics of the disease especially rainy season prevalence.

Masiga, W.N., Domenech, J. and Windor, R.S. (1996). Manifestation and Epidemiology of Contagious Bovine Pleuropneumonia in Arica. Review Scientific Technical Institute of Epizootics, 15, 1283 - 1308.

Mikail, B.A. (2001). Deforestation and Afforestation Policy Aimed at Sustaining the Land Resources of Jigawa state. An invited paper presented at the Senior Executive Seminar on Policy and Strategies. March 14, 2001.

Musisi, F.L., Dungu, B., Twala, R., Mogujane, M.E. and Matei, B.J. (2011). The Threat of Contagious Bovine Pleuropneumonia and Challenges for its Control in the SADC Region Retrieved 20/06/11, 2011, from http://www.fao.org/docrep/ 007/y5510e0d.htm.

Nawathe, D.R. (1992). Resurgence of Contagious Bovine Pleuropneumonia in Nigeria. Revue Science Technical Office International Epizootics 11: 799 - 804.

Odo, B.I. (2003). Comparative Study of some Prevalent Diseases of Ecotype Goats Reared in Southeastern Nigeria. Small Ruminants Research. 50: 203 - 207.

OIE, (1995). Meeting of the FMS and Other Epizootics Commission. OIE, Paris, $16-20$.

Penin, A. and Mahabile, M. (1997). Profitability and Household Income Contribution of Small Ruminants to Small Scale Farmers in Botswana. Small Ruminant Research. 25: 9 $-15$.

Statistical Analysis System Institute, (1989). User's Guide for Personal Computers. SAS Institute Inc., Cary, N.C.

Thorntons, H. and Gracey, J.F. (1981). Thorntons Meat Hygiene. $7^{\text {th }}$ ed. Sassel Ltd., London. Pp. $120-128$.

Tores, J., Meens, J., Bruetter, F.F.R., Linz, B., Naessens, J. and Gerlach, G.F. (2009). Analysis of the Immunoproteome of Muycoplasma muycoides subsp. Mycoides, Small Colony Type Reveals Immunogenic Homologues to Other known Virulence Traits in Related Mycoplasma species. Veterinary Immunology and Immunopathogloy, 131(3 $-4), 238-245$. 